\title{
Targeted expression of MDM2 uncouples $S$ phase from mitosis and inhibits mammary gland development independent of p53
}

\author{
Karen Lundgren, ${ }^{1,2,4}$ Roberto Montes de Oca Luna, ${ }^{3}$ Yvette Boddie McNeill, ${ }^{1}$ Elena P. Emerick, ${ }^{1,5}$ \\ Ben Spencer, ${ }^{1}$ Cynthia Rahn Barfield, ${ }^{1}$ Guillermina Lozano, ${ }^{3}$ Michael P. Rosenberg, ${ }^{1,2}$ and Cathy A. \\ Finlay ${ }^{2,6}$ \\ ${ }^{1}$ Transgenic Mouse Group and ${ }^{2}$ Cell Cycle Project, Glaxo Wellcome Research and Development, Research Triangle Park, \\ North Carolina 27709 USA; ${ }^{3}$ Department of Molecular Genetics, University of Texas MD Anderson Cancer Center, \\ Houston, Texas 77030 USA
}

MDM2 is a cellular protein that binds to and inactivates the p53 tumor suppressor protein. Although mdm2 has been shown to function as an oncogene in vitro, all studies to date have assessed MDM2 activities in the presence of p53, implicating p53 inactivation in MDM2-directed transformation. To determine the role of MDM2 in the cell cycle and in tumorigenesis and whether or not this role is dependent on p53, an MDM2 minigene was expressed during gestation and lactation in the mammary gland of both wild-type p53 $(\mathrm{p} 53+/+)$ and p53 knockout (p53-/-) mice using the bovine $\beta$-lactoglobulin promoter. In six different transgenic mouse lines, deregulated expression of MDM2 inhibited normal development and morphogenesis of the mammary gland, and caused cellular hypertrophy and nuclear abnormalities. These abnormalities included both multinucleated cells and enlarged cells with giant nuclei. Although there were fewer epithelial cells present in the transgenic mammary gland, no apoptosis was observed. Instead, BrdU incorporation and PCNA staining showed that $12 \%-27 \%$ of the transgenic mammary epithelial cells were in $\mathrm{S}$ phase at a time when normal cells were terminally differentiated. Analysis of DNA content showed that $30 \%-45 \%$ of the cells were polyploid, with DNA contents up to $16 \mathrm{~N}$, indicating that overexpression of MDM2 caused mammary epithelial cells to undergo multiple rounds of $S$ phase without cell division. This phenotype was similar in the p53+/+ and p53-/- background, demonstrating a role for MDM2 in the regulation of DNA synthesis that is independent of the ability of MDM2 to inhibit p53 activity. Additionally, multiple lines of BLGMDM2 transgenic mice developed mammary tumors, confirming that overproduction of MDM2 contributes to tumorigenesis in epithelial cells in vivo.

[Key Words: mdm2; p53; transgenic mice; cell cycle; tumor]

Received December 13, 1996; revised version accepted February 11, 1997.

The MDM2 cellular protein interacts with the p53 tumor suppressor and inhibits p53 function (Momand et al. 1992). Specifically, MDM2 binds to the amino-terminal acidic domain of p53 and inhibits p53 transactivation (Chen et al. 1993; Oliner et al. 1993). In addition, overexpression studies in tissue culture have demonstrated that MDM2 can inhibit wild-type p53-mediated $\mathrm{G}_{1}$ arrest and apoptosis (Chen et al. 1996; Haupt et al. 1996). The relationship between p53 and MDM2 extends beyond protein-protein interaction. P53 can bind to p53.

Present addresses: ${ }^{4}$ Agouron Pharmaceuticals, Inc., San Diego, California 92121 USA; ${ }^{5}$ Analytical Sciences, Inc., Durham, North Carolina 27713 USA.

${ }^{6}$ Corresponding author.

E-MAIL Finlay CA@GLAXOWELLCOME.COM; FAX (919) 315-5243. responsive elements within the promoter of the mdm2 gene and activate $m d m 2$ transcription, thus establishing a negative feedback loop (Barak et al. 1993; Juven et al. 1993; Wu et al. 1993).

Additional clues to the role of the MDM2-p53 interaction have been obtained from deletion of the $m d m 2$ gene in mice (Jones et al. 1995; Montes de Oca Luna et al. 1995). Mice that are null for MDM2 function are nonviable by day 5 of gestation, whereas mice null for $p 53$ are viable but predisposed to tumors, succumbing to lymphoma and other tumors from 4 to 6 months of age (Donehower et al. 1992; Jacks et al. 1994). Crossing $m d m 2$ and $p 53$ mutant mice yielded viable progeny that were null for both genes. The rescue of the mdm2-1lethality demonstrated that the ability of MDM2 to inhibit p53 function is critical during early mouse development. 
MDM2 was discovered independent of the interaction with p53, as a gene amplified on double-minute chromosomes in a tumorigenic murine cell line (Cahilly-Snyder et al. 1987; Fakharzadeh et al. 1991). The overexpression of $m d m 2$ confers a tumorigenic phenotype to NIH-3T3 cells (Fakharzadeh et al. 1991) and cooperates with an activated ras gene to transform primary rat embryo fibroblasts (Finlay 1993). In addition, amplification of the $m d m 2$ gene has been observed in $30 \%-40 \%$ of human sarcomas (Oliner et al. 1992; Ladanyi et al. 1993; Leach et al. 1993; Reifenberger et al. 1993; Cordon-Cardo et al. 1994) and with a low frequency in human carcinomas (Sheikh et al. 1993; Fontana et al. 1994; Quesnel et al. 1994; Marchetti et al. 1995; McCann et al. 1995). The majority of tumors overexpressing $m d m 2$ retained a wild-type p53 gene, suggesting that MDM2 can effectively overcome p53 tumor suppressor activity. Some tumors, however, appear to have both mutant p53 and overexpressed MDM2, indicating that both events could contribute to tumor development (Cordon-Cardo et al. 1994).

Recent studies have provided evidence implicating MDM2 as a regulatory protein in the $G_{1} / S$ transition period of the cell cycle through interactions with both the E2F1 transcription factor and the retinoblastoma $(\mathrm{Rb})$ tumor suppressor protein in vitro. MDM2 can bind to and stimulate E2F1/DP1 transcriptional activity (Martin et al. 1995), which functions as a positive regulator for entry into $\mathrm{S}$ phase. MDM2 also interacts with $\mathrm{Rb}$ to inhibit $\mathrm{Rb}$ growth regulatory function (Xiao et al. 1995). Taken together, the MDM2 interactions and activities characterized to date suggest that MDM2 plays a role in promoting entry into $\mathrm{S}$ phase.

To assess the role of the MDM2 protein in cell cycle regulation and tumorigenesis, and how the interaction between MDM2 and p53 affects these functions, we targeted expression of an MDM2 minigene to the mammary gland in both wild-type and p53-/- mice using the ovine milk protein promoter $\beta$-lactoglobulin (BLG). The mammary gland is a particularly good model because epithelial cells undergo a normal cycle of proliferation, differentiation, and apoptosis during pregnancy, lactation, and involution following weaning. Promoters that target expression of exogenous genes to the mammary gland have been used to assess the role of genes in cell cycle regulatory pathways, development, and tumorigenesis (Cardiff and Muller 1993). In the mammary gland, tumors have arisen in mice with deregulated expression of c-neu, c-myc, Ha-ras, Wnt-1, int-2, transforming growth factor- $\alpha$ (TGF- $\alpha$ ), and cyclin D (for review, see Cardiff and Muller 1993; Cardiff and Munn 1995; Amundadottir et al. 1996). In most instances, tumors arise from focal lesions in a time course delayed relative to initial transgene expression, suggesting that secondary events are necessary for tumorigenesis.

The data presented in this report demonstrate that overproduction of MDM2 during pregnancy and lactation results in defective development of the mammary gland. The lack of development observed in the transgenic mammary gland resulted from multiple rounds of
$S$ phase without completion of mitosis. This uncoupling of $\mathrm{S}$ phase from mitosis was observed in BLGMDM2 transgenic mice in both the wild-type p53 and the p53-/- backgrounds, demonstrating a role for MDM2 that is independent of p53 function. In addition, mammary tumors have developed in mice bearing the BLGMDM2 transgene from 14 to 18 months of age, demonstrating that deregulated expression of MDM2 can contribute to tumor formation in the mammary gland.

\section{Results}

Targeted expression of MDM2 in the murine mammary gland

To determine the effect of deregulating MDM2 expression in an in vivo system, the ovine BLG promoter was used to direct expression of an $m d m 2$ minigene to the murine mammary gland. The BLG promoter has been shown to confer tissue-specific, hormonally regulated expression of heterologous genes to the mammary epithelial cells of transgenic mice during pregnancy and lactation (Harris et al. 1991). The construct consists of the $m d m 2$ cDNA containing the seventh and eighth genomic introns (Montes de Oca Luna et al. 1996) cloned into a BLG vector and is designated BLGMDM2 (Fig. 1A). The transgene was excised from plasmid DNA, and the 9.7$\mathrm{kb}$ linear fragment was microinjected into the pronuclei of B6C3F2 mouse embryos (Osborn et al. 1987). Transgenic founder animals were identified by PCR analysis and confirmed by Southern blotting (data not shown). From these founders, nine independent lines of transgenic mice were established by backcrossing to C57B1/6J mice.

To assess the expression of the $m d m 2$ minigene, total RNA was isolated from mid-lactation (day 8-12) mammary glands of transgenic and nontransgenic siblings and subjected to $\mathrm{T} 2 \mathrm{RNase}$ protection analysis. The $\mathrm{BamHI}$ fragment of the $m d m 2$ minigene was subcloned into Bluescript $\mathrm{KS}^{+}$, and antisense RNA was synthesized for the probe (Fig. 1B). RNase expression analysis of midlactation mammary glands from each of the six highest expressing lines is shown in Figure 1C. The 771-nucleotide antisense $m d m 2$ probe contained 408 nucleotides of homology to the spliced transgene and 739 nucleotides of homology to the unspliced transgene (cDNA plus genomic intron). Both the spliced and unspliced forms were detected in the RNase protection assay (Fig. 1C). The endogenous murine mdm2 RNA was detected as a 402-base band in overexposed gels (data not shown). For an internal control, a 300-nucleotide antisense riboprobe containing a 250-nucleotide region of homology to the murine $\beta$-actin gene (Ambion) was used. The expression of the BLGMDM2 transgene was 10 to 30 times that of endogenous $m d m 2$ levels in independent lines. In addition to the mammary gland, expression of the BLGMDM2 transgene transcript was analyzed using RNA from salivary gland, spleen, kidney, liver, lung, heart, eye/harderian gland, and brain and was not detected in any of these tissues (data not shown). Of the nine origi- 


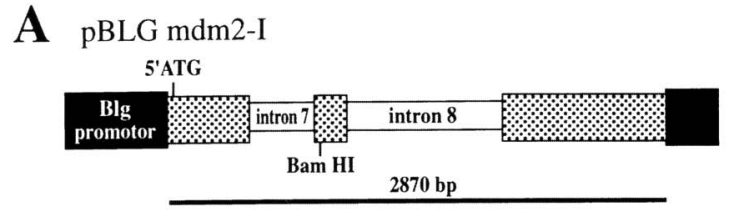

B pmdm2 Bam HI KS+

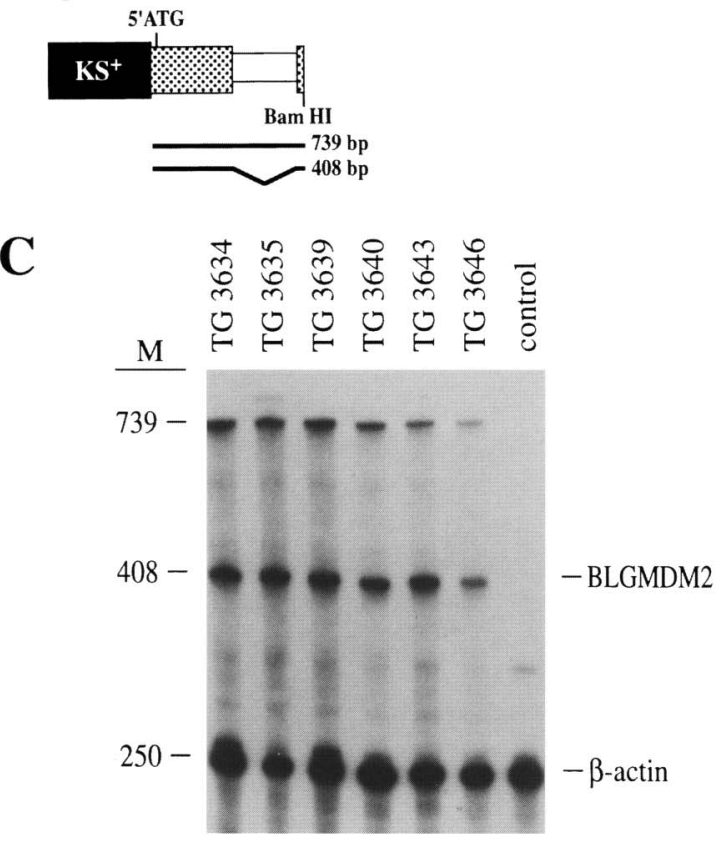

Figure 1. Generation of BLGMDM2 transgenic lines. $(A)$ The BLGMDM2 transgene construct contains the BLG promoter (left solid box) and the full-length normal mdm2 coding sequence (stippled boxes) interrupted by introns 7 and 8 (open boxes) followed by the poly(A) tail from the BLG gene (right solid box). (B) The fragment used to generate the RNA probe for T2 RNase expression analysis protects transgene RNA of 408 bases. (C) T2 RNase expression analysis of mid-lactation mammary glands from the six highest expressing BLGMDM2 transgenic lines.

nal lines generated, the six shown expressing the highest levels of MDM2 were analyzed further, two in great detail.

Time course of BLGMDM2 expression in the mammary gland during pregnancy and lactation

The transgenic line TG3640 displayed both a high level of mdm2 RNA expression (Fig. 1C) and developmental abnormalities in the mammary gland in preliminary biopsies, and so it was chosen for further analysis. To trace the initiation and development of the abnormalities, mammary glands from mice of line TG3640 were analyzed histologically and for expression of the transgene in a time course experiment. RNA expression (Fig. 2) and hematoxylin and eosin (H\&E)-stained sections (Fig. 3) from control and transgenic glands were compared at day 10 and 15 of gestation, day 1, 5, 10, and 15 of lactation, and day 10 postweaning. Figure 2 shows the quantitation of three different RNase protection experiments that were averaged and graphed over the time course relative to endogenous mdm2 RNA levels. In the control animals, no transgenic mdm2 RNA was detected. Transgenic $m d m 2$ RNA levels were twice the endogenous levels at day 10 of gestation, increased to 12 times the endogenous levels at the end of gestation, and increased to 22 times the endogenous levels by day 5 of lactation. Expression then decreased gradually thereafter.

Concurrent with RNA analysis, a histological examination was performed. The time course of mammary gland development in control animals is shown in Figure 3 . In the normal mammary gland, epithelial cells began proliferating during gestation (Fig. 3A,C) until 1 day after parturition, when they form the lobulo-alveolar structures that secrete milk (Fig. 3E, day 1 of lactation). Mammary epithelial cells began to differentiate prior to parturition, and by day 5 of lactation (Fig. 3G), the cells that form the alveoli were terminally differentiated and mitotically quiescent. In comparison, mammary glands from BLGMDM2 transgenic mice did not develop normally. At day 10 (Fig. 3A,B) and 15 of gestation (Fig. $3 \mathrm{C}, \mathrm{D})$, control and transgenic glands showed similar growth and development. By day 1 of lactation, however, the transgenic gland (Fig. 3F) appeared to be less devel-

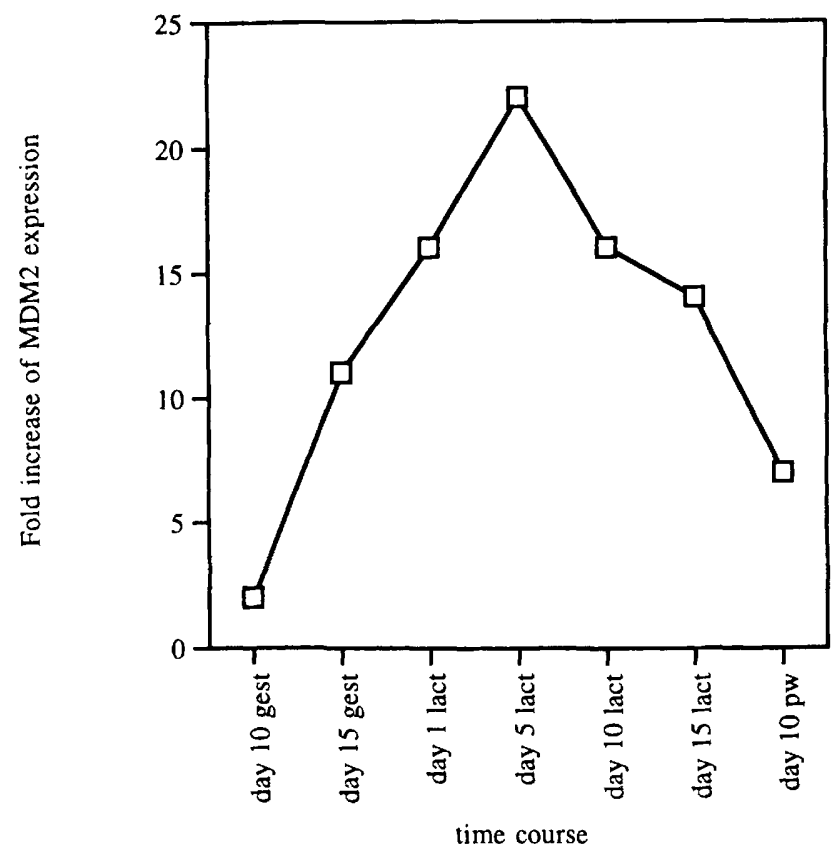

Figure 2. Time course of BLGMDM2 transcript expression during pregnancy and lactation. The relative amount of BLGMDM2 (TG3640) RNA expression was calculated and averaged from three separate $\mathrm{T} 2$ RNase experiments. The ratio of transgene MDM2 expression to endogenous MDM2 levels in control mice (seen only with overexposure of the gel) was calculated after compensation for actin levels. Transcripts were quantitated with a Molecular Dynamics PhosphorImager. (gest) Gestation; (lact) lactation; (pw) postweaning. 


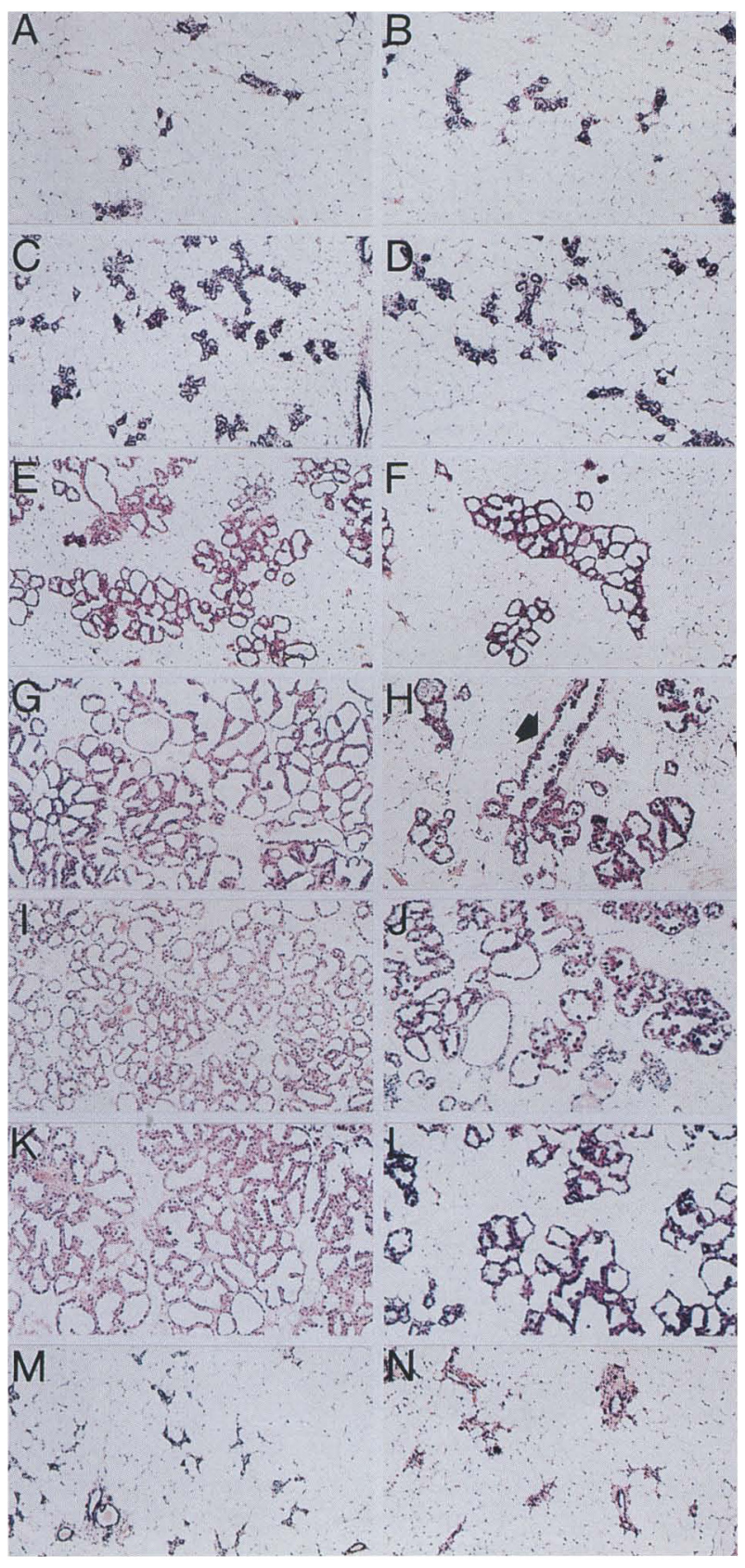

Figure 3. Histological analysis of normal and BLGMDM2 (TG3640) mammary glands during pregnancy and lactation. Paraffin sections of mammary tissue taken at various times during the lactation cycle were stained with H\&E. Mammary glands from control mice at day 10 of gestation $(A)$; day 15 of gestation $(C)$; day 1 of lactation $(E)$; day 5 of lactation $(G)$; day 10 of lactation $(I)$; day 15 of lactation $(K)$; day 10 of postweaning $(M)$. Mammary glands from BLGMDM2 mice at day 10 of gestation $(B)$; day 15 of gestation $(D)$; day 1 of lactation $(F)$; day 5 of lactation $(H$; arrow points to ductal hyperplasia visible as a piling up of cells one on top of another, day 10 of lactation $(J)$; day 15 of lactation $(L)$; and day 10 of postweaning $(N)$. $(A-N)$ Magnification, $100 \times$. oped than the control gland (Fig. 3E). On days 5, 10, and 15 of lactation a striking lack of development was apparent in the transgenic glands (Fig. $3 \mathrm{H}, \mathrm{J}, \mathrm{L}$, respectively) relative to control glands (Fig. 3G,I,K, respectively). The mammary gland of the transgenic mice contained fewer lobulo-alveolar structures and fewer epithelial cells. The epithelial cells lining the basement membrane of the alveoli and ducts had larger nuclei, which stained atypically compared with controls. Ductal hyperplasia was also apparent in the BLGMDM2 transgenics, as shown in the histological section from day 5 of lactation (Fig. $3 \mathrm{H}$, arrow). Whereas normal ducts were lined with a single layer of epithelial cells, the transgenic glands contained cells that piled up along the walls of the ducts. The lack of glandular development resulted in lactation difficulties, so much so that the pups were routinely fostered at birth. Both the control and transgenic glands regressed normally at weaning (Fig. $3 \mathrm{M}, \mathrm{N}$ ). Overall, the appearance of the developmental abnormalities correlated well with the time course of induced transgene expression (Fig. 2).

Comparison of mammary gland development in p53-/- and BLGMDM2 transgenic mice

Because the MDM2 protein can inhibit p53 function (Momand et al. 1992; Chen et al. 1993; Oliner et al. 1993), we asked whether the loss of p53 resulted in a phenotype similar to that of $m d m 2$ overexpression. The development of mammary glands in control, p53-/-, and BLGMDM2 (TG 3640) transgenic mice were compared at day 10 of lactation. Whole-mount analysis revealed that, whereas both the control and p53-/- glands were fully developed (Fig. 4A and B, respectively), the BLGMDM2 gland had fewer alveolar structures that cluster together to form lobules (Fig. 4C). The lack of mammary gland development made it possible to see individual ducts (Fig. 4C), which are normally masked by the alveolar lobules in a fully developed nontransgenic lactating gland (Fig. 4A). Comparison of $\mathrm{H} \& \mathrm{E}$ stained sections from control (Fig. 4D) and p53-/- (Fig. 4E) mammary glands at day 10 of lactation showed a similar morphology, that of a single layer of columnar epithelial cells lining the ducts and alveoli. It has been reported previously that p53-/- mice develop normally and are able to nurse their pups (Donehower et al. 1992; Li et al. 1996). By comparison, the ductal and alveolar cells of the BLGMDM2 gland (Fig. 4F) were abnormal: Fewer epithelial cells were present in the alveoli, and the cells were typically two to three times larger than the controls. Histological analysis of 500 epithelial cells of the transgenic gland showed that $28 \%$ had enlarged nuclei, $13 \%$ were bi- or multinucleate, and $5 \%$ were binucleate and enlarged. Occasional mitotic figures were also observed $(<1 \%)$. All six lines expressing high levels of the BLGMDM2 transgene were evaluated histologically, and similar phenotypes were observed. MDM2 expression was monitored using immunohistochemical analysis with an MDM2-specific polyclonal antiserum. Sections from BLGMDM2 mammary glands (TG3640) showed el- 
Lundgren et al.

Figure 4. Comparison of mammary glands from normal, p53-/-, and BLGMDM2 (TG3640) mice at day 10 of lactation. Whole mounts of mammary glands were analyzed from control $(A), \mathrm{p} 53-/-(B)$, and BLGMDM2 $(C)$ mice. $(A-C)$ Magnification, $80 \times . H \& E$ stained sections of glands from control $(D)$, p53-/ $-(E)$, and BLGMDM2 $(F)$ mice. Immunohistochemical detection of MDM2 from control $(G), \mathrm{p} 53-/-(H)$, and BLGMDM2 $(I)$ mammary sections. $(D-I)$ Magnification, 400x.

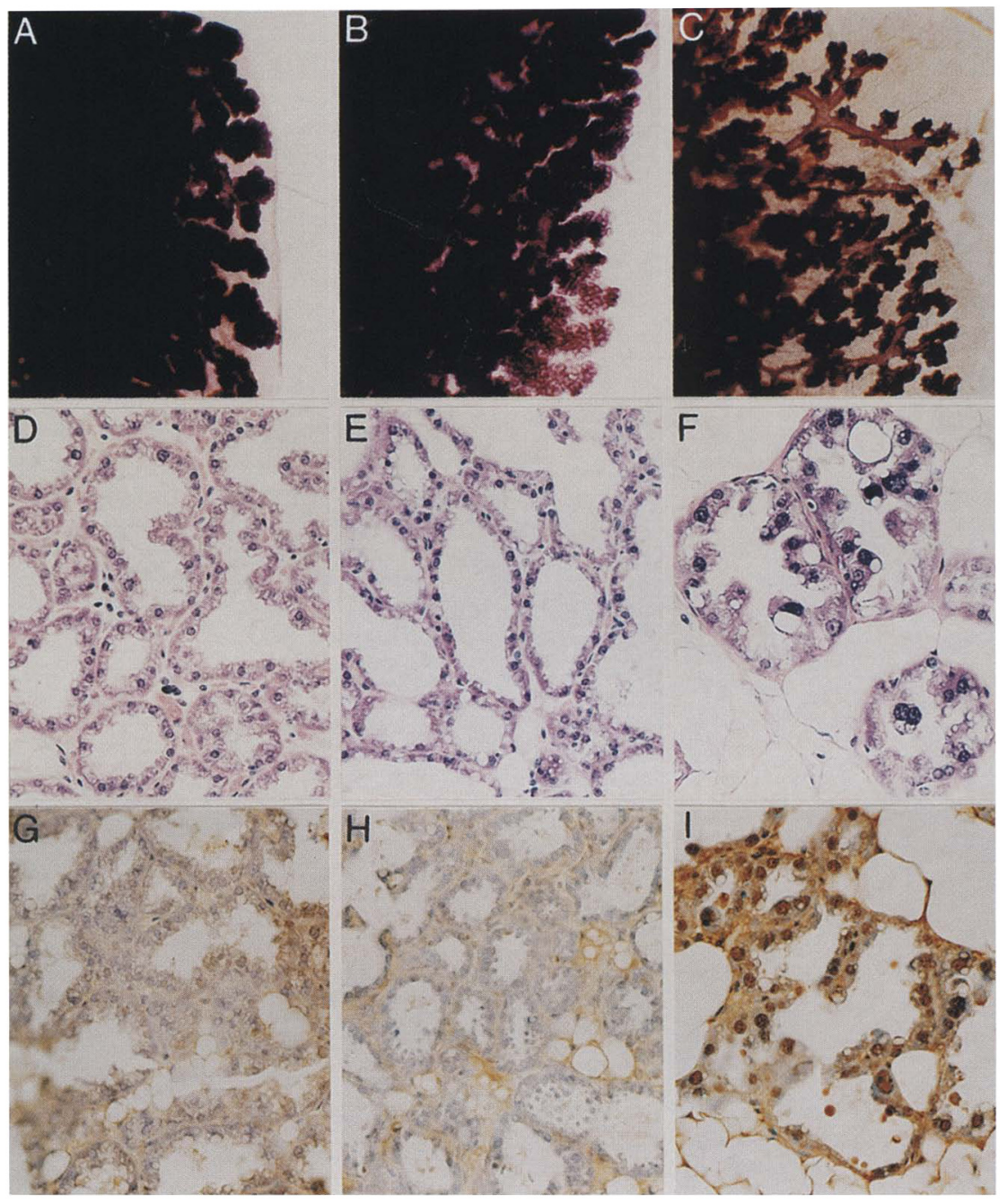

evated expression of MDM2 in the nuclei of mammary epithelial cells from day 10 of lactation (Fig. 4I) relative to sections from either control or p53-/- mice (Fig. $4 \mathrm{G}, \mathrm{H})$.

\section{Cell cycle analysis of cells from BLGMDM2 transgenic glands}

Our results demonstrated that MDM2 overexpression during the lactation cycle in the mammary gland of transgenic mice results in a decrease in epithelial cell number and inhibits gland development. To determine whether the decrease in the number of epithelial cells seen in BLGMDM2 transgenic mice was a result of an increased level of apoptosis, an in situ terminal deoxytransferase (TdT) assay was performed. Less than $1 \%$ of mammary epithelial cells in the control and transgenic mammary glands stained positively for apoptosis at day 10 lactation, demonstrating that apoptosis did not account for the decrease in the number of cells in the BLGMDM2 transgenic gland (data not shown).

The lack of mammary gland development coupled with the presence of epithelial cells abnormally large and multinucleated led to further studies of the cell cycle in BLGMDM2 mice. To investigate the effect of MDM2 expression on proliferation of mammary epithelial cells, the percentage of cells in $S$ phase was examined in nontransgenic control, p53-/- and BLGMDM2 TG3640 transgenic mice at day 10 of lactation (Fig. $5 \mathrm{~A}-\mathrm{C}$ ) using bromodeoxyuridine ( $\mathrm{BrdU})$ incorporation as an index. As expected, few epithelial cells from control and p53-/glands, which are terminally differentiated by day 10 of lactation, were synthesizing DNA actively. Less than $1 \%$ of the control cells incorporated BrdU (Fig. 5A), whereas $\sim 4 \%$ of mammary epithelial cells in the p53-/gland incorporated BrdU (Fig. 5B). Surprisingly, 12\% and $23 \%$ of the mammary epithelial cells from BLGMDM2 glands from two transgenic lines (TG3639 and TG3640, respectively/ incorporated $\mathrm{BrdU}$ at day 10 of lactation (Fig. 5C; Table 1), indicating these cells are synthesizing DNA actively.

As an alternate method of determining the fraction of cells undergoing DNA synthesis, detection of the proliferating cell nuclear antigen (PCNA) was used to identify 


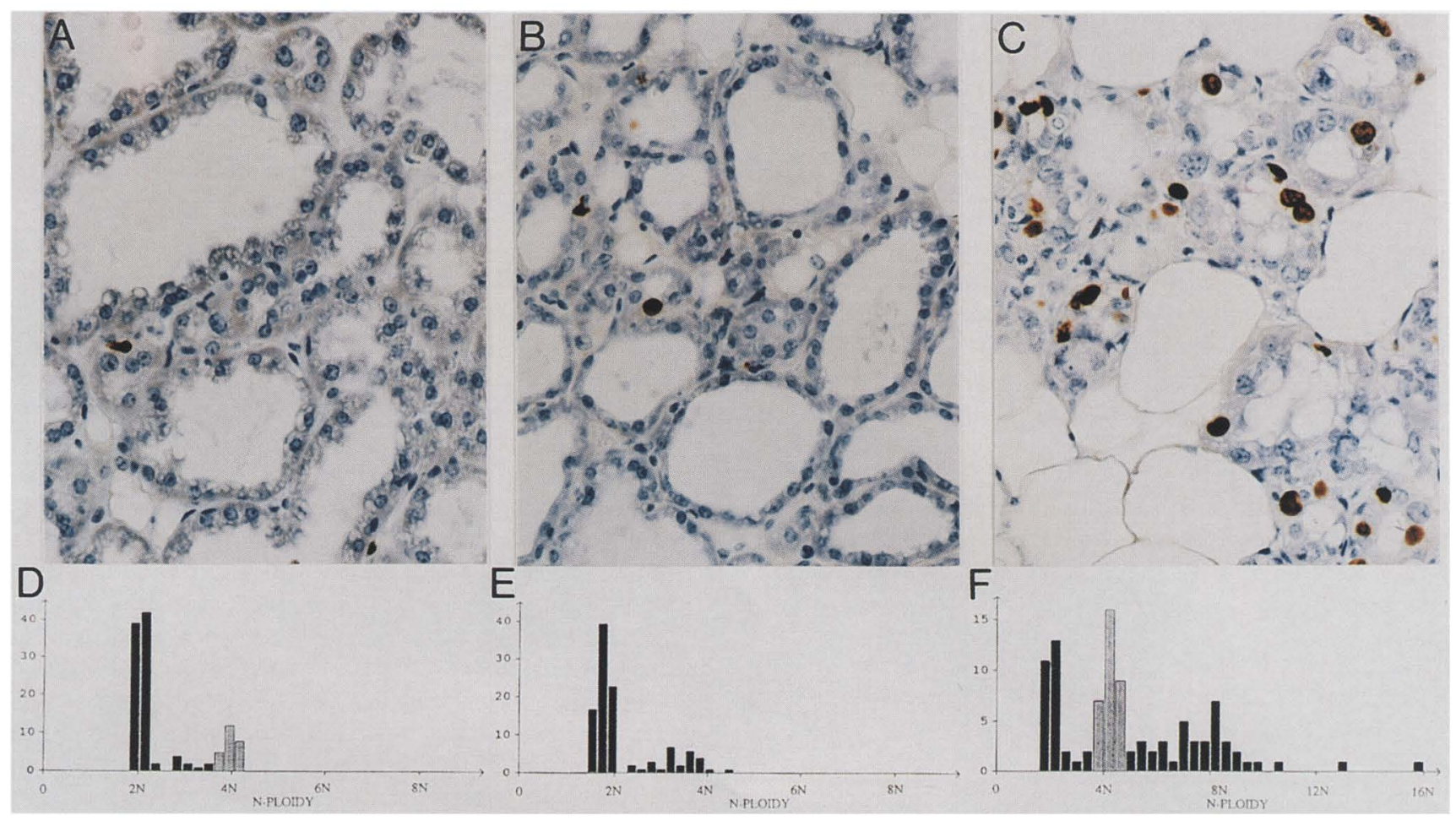

Figure 5. Detection of BrdU incorporation and ploidy analysis in epithelial cell nuclei of control, p53-/-, and BLGMDM2 (TG3640) transgenic mammary glands. Immunohistochemistry was used to detect BrdU in nuclei of mammary epithelial cells from control $(A)$, p53- $/-(B)$, and BLGMDM2 $(C)$. $(A-C)$ Magnification, 400x. Histograms of DNA content showing the nuclear ploidy of control $(D)$, p53-/- $(E)$, and BLGMDM2 $(F)$ mammary epithelial cells. The $y$-axis represents cell numbers.

cells in S phase in situ (Foley et al. 1991). PCNA staining analysis was performed in control, p53-/-, and two different lines of BLGMDM2 transgenic mice (Table 1). In this study, BrdU incorporation and the results from PCNA staining correlated well. Two glands analyzed from each of two TG3640 and two TG3639 mice showed that the BLGMDM2 S-phase index was four to five times that of the p53-/- mice (Table 1).

To investigate the apparent paradox that MDM2 overexpression increased the S-phase index yet did not result in an increase in the number of epithelial cells, we analyzed cells for ploidy. Ploidy analysis was carried out by quantitating the relative optical density (OD) of Feulgenstained nuclei (Schiff's reagent) using the DNA Image Cytometry system (LabCorp). The Feulgen reaction product binds stoichiometrically to DNA so that the integrated OD obtained by image cytometry is proportional to the amount of DNA in the nucleus (Schulte and Wittekind 1989|. Mammary epithelial cell nuclei from control mice were used to establish $2 \mathrm{~N}$ and 4N DNA

Table 1. Cell cycle analysis of mammary epithelial cells from BLGMDM2 transgenic mice

\begin{tabular}{|c|c|c|c|c|c|}
\hline \multirow[b]{2}{*}{ Mouse } & \multirow[b]{2}{*}{ BrdU labeling index ${ }^{a}$} & \multirow{2}{*}{$\begin{array}{l}\text { PCNA S-phase } \\
\text { labeling index }\end{array}$} & \multicolumn{3}{|c|}{ Ploidy $^{\mathrm{c}}$} \\
\hline & & & $2 \mathrm{~N}$ & $4 \mathrm{~N}$ & $>4 \mathrm{~N}$ \\
\hline Control & $1 \%(11 / 1091)$ & $1 \%(17 / 1202)$ & $66 \%(287 / 438)$ & $34 \%(151 / 438)$ & 0 \\
\hline $\begin{array}{l}\text { p53-/- } \\
\text { BLGMDM2 }\end{array}$ & $4 \%(79 / 2182)^{\mathrm{d}}$ & $5 \%(48 / 1032)^{\mathrm{d}}$ & $80 \%(334 / 419)$ & $20 \%(85 / 419)$ & 0 \\
\hline TG 3639 & $12 \%(195 / 1668)$ & $18 \%(196 / 1072)$ & $20 \%(81 / 407)$ & $40 \%(163 / 407)$ & $40 \%(163 / 407)$ \\
\hline BLGMDM2 & & & & & \\
\hline TG 3640 & $22 \%(194 / 892)$ & $24 \%(238 / 1008)$ & $27 \%(129 / 471)$ & $39 \%(186 / 471)$ & $33 \%(156 / 471)$ \\
\hline
\end{tabular}

BrdU labeling, PCNA staining, and ploidy analysis were conducted on two mammary glands from each of two control, p53-/-, BLGMDM2 TG3639, and BLGMDM2 TG3640 mice.

${ }^{a}$ Percentage of mammary epithelial cells labeled with BrdU after a 1-hr pulse (positive cells/total examined).

${ }^{b}$ Percentage of mammary epithelial cells that stain with anti-PCNA antibody (positive cells/total examined).

${ }^{\text {c} P e r c e n t a g e ~ o f ~ m a m m a r y ~ e p i t h e l i a l ~ c e l l ~ n u c l e i ~ w i t h ~ D N A ~ c o n t e n t ~ o f ~} 2 \mathrm{~N}, 4 \mathrm{~N}$, or $>4 \mathrm{~N}$ (positive cells/total examined).

${ }^{\mathrm{d}}$ Analysis conducted on two mammary glands from one mouse. 
values. The OD of DNA in p53-/- and BLGMDM2 transgenic nuclei was then used to calculate the relative OD. The data showed that nuclei from both control (Fig. 5D) and p53-/- (Fig. 5E) epithelial cells were predominantly in $\mathrm{G}_{1}$ with a DNA content peak at $2 \mathrm{~N}$ in the fully differentiated day 10 lactation gland. In contrast, BLGMDM2 mammary epithelial nuclei (Fig. $5 \mathrm{~F}$ ) were found to be polyploid, with $\mathrm{OD}$ values at $4 \mathrm{~N}, 8 \mathrm{~N}$, and $16 \mathrm{~N}$, or up to eight copies of a genomic equivalent, relative to the normal DNA content. Ploidy analysis also revealed a population of nuclei with intermediate DNA contents (relative to $4 \mathrm{~N}, 8 \mathrm{~N}$ ), but we could not determine whether the nuclei with intermediate DNA content were synthesizing DNA actively at the time of analysis. Results from DNA image analysis indicated that $35 \%$ to $40 \%$ of the nuclei from BLGMDM2 mammary epithelial cells were polyploid, suggesting that deregulated expression of MDM2 led to multiple rounds of DNA synthesis without cytokinesis.

\section{The phenotype caused by deregulated expression of $M D M 2$ is independent of $p 53$ function}

To determine the contribution of p53 to glandular abnormalities and polyploidy resulting from MDM2 overexpression, BLGMDM2 mice (TG 3640) were crossed into the p53-/- background. PCR analysis was used to genotype the animals used in this study (Fig. 6). Histological samples from the p53-/- and BLGMDM2/ p53-/- mammary glands are shown in Figure $7 \mathrm{~A}$ and $\mathrm{B}$, respectively. The BLGMDM2/p53-/- mammary gland showed a lack of development and fewer lobulo-alveolar structures with enlarged and multinucleated cells (Fig. $7 \mathrm{~B})$, very similar to the BLGMDM2 transgenic mammary gland (Fig. 4F). BrdU incorporation studies (Fig. 7C,D) and ploidy analysis (Fig. $7 E, F)$ showed that $18 \%$ of the mammary epithelial cells were undergoing DNA synthesis, and $29 \%$ of the nuclei were polyploid in BLGMDM $2 /$ p53-/- mice. These results demonstrate that deregu-

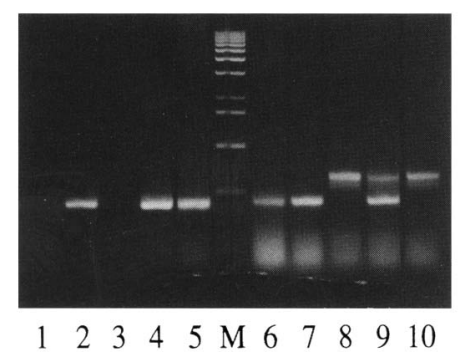

Figure 6. Genotyping of p53 homozygous null/BLGMDM2 transgenic animals. (Lanes 1-5) PCR was performed with BLGMDM2 primers. (Lane 1) Nontransgenic wild-type p53; (lane 2) TG3640 BLGMDM2; (lane 3) p53-/-; (lane 4) TG3640 BLGMDM2/p53+/-; (lane 5) TG3640 BLGMDM2 p53-/-. (Lanes 6-10) PCR analysis was performed with p53 primers. (Lane 6$)$ Wild-type p53; (lane 7) TG 3640 BLGMDM2; (lane 8) p53-/-; (lane 9) TG3640 BLGMDM2 p53+/-; (lane 10) BLGMDM2/ p53-/-. lated expression of MDM2 in the mammary gland of transgenic mice uncoupled $\mathrm{S}$ phase from karyokinesis and/or cytokinesis, independent of p53.

\section{Development of mammary tumors in BLGMDM2 transgenic mice}

Previous studies have demonstrated $m d m 2$ can function as an oncogene in vitro and is frequently amplified in human sarcomas (Fakharzadeh et al. 1991; Oliner et al. 1992; Finlay 1993), suggesting that MDM2 overproduction is a causative factor in tumor formation. Aging studies were performed on retired breeders to ascertain the tumorigenic potential of $m d m 2$ deregulation. To date, tumors have been observed in $5 / 31(16 \%)$ retired breeders (lines TG3640, TG3643, and TG3646). These tumors developed in mammary glands between 14 and 18 months of age. In addition, multiple tumors in multiple glands were observed in these mice. No incidence of mammary tumor formation has been observed in nontransgenic or inbred C57BL/6J control mice maintained for up to 18 months in our colonies (data not shown). Figure 8 shows representative histological sections from two of the mammary tumors. Figure $8 \mathrm{~A}$ shows an adenocarcinoma with characteristic acinar structures adjacent to an adenoacanthoma, which has a mixture of glandular tumor tissue and keratinized epidermoid tissue. An adenocarcinoma from another animal that appeared more ductal in structure is shown in Figure 8B. In addition to the tumors, hyperplasia and characteristic preneoplastic hyperplastic alveolar nodules (HANs) were evident in several glands of aged animals (data not shown). Western blot analysis demonstrated the presence of MDM2 protein in tumors from two BLGMDM2 mice (Fig. 8C). MDM2 expression was undetectable in normal mammary tissue (data not shown). As a control for MDM2 protein, the mdm2-amplified 3T3 DM cell line (Fakharzadeh et al. 1991) was used. Transgenic $m d m 2$ expression was confirmed using $\mathrm{T} 2$ RNase protection analysis (data not shown).

\section{Discussion}

The present study describes the phenotype of transgenic mice with deregulated expression of MDM2 in the mammary gland during gestation and lactation. Three important points demonstrated by the data presented in this paper need to be emphasized. First, MDM2 overexpression resulted in cell cycle abnormalities and poorly developed mammary glands during gestation and lactation. S-phase analyses showed that transgenic epithelial cells were actively undergoing DNA synthesis, and ploidy analysis demonstrated that the cells had undergone multiple rounds of replication without completing cell division. Second, these effects occurred independently of the presence of p53. Mammary epithelial cells overexpressing MDM2 and null for p53 had a high S-phase index accompanied by an increase in polyploid cells comparable to that observed in a transgenic MDM2 wildtype p53 background. Third, deregulated expression of 

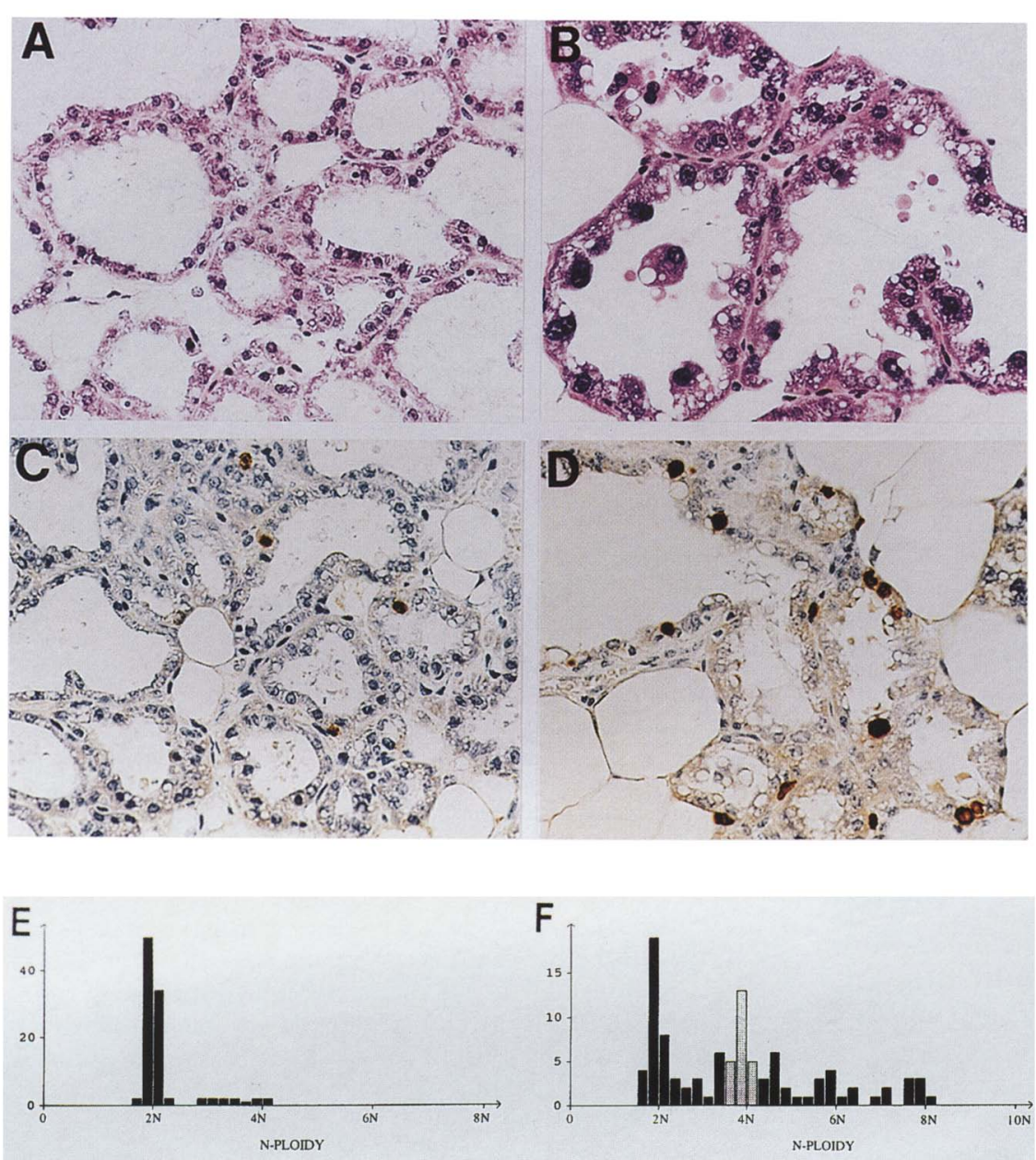

Figure 7. Comparison of histology and ploidy of mammary epithelial cells from glands of p53-/- and TG3640 BLGMDM2/ p53-/- mice. H\&E staining of sections from p53-/ - $(A)$ and BLGMDM2/p53-/(B) mammary glands. Immunohistochemistry was used to detect BrdU incorporation in mammary epithelial cells of p53-/$(C)$ and BLGMDM2/p53-/- $(D)$ mice. $(A-$ D) Magnification, $400 \times$. Histograms of DNA content showing ploidy of $\mathrm{p} 53-/-(E)$ and BLGMDM $2 / \mathrm{p} 53-/-\langle F\rangle$ mammary epithelial cells. The $y$-axis represents cell numbers.
MDM2 can result in mammary tumor development following a long latency. Tumors have been observed in $\sim 16 \%$ of animals by $14-18$ months of age.

The deregulated expression of MDM2 in the mammary gland during gestation and lactation resulted in a loss of coordination between DNA synthesis and mitosis; however, the mechanisms underlying this phenotype have not been defined. MDM2 overproduction may induce the initiation (and reinitiation) of S phase, prevent S-phase completion, or inhibit entry into mitosis. Given what is known about MDM2 function, the hypothesis we favor most is that MDM2 overexpression can constitutively provide signals that repeatedly induce the initiation of DNA synthesis, but cannot induce all of the cellular pathways necessary for an orderly transition into $G_{2}$ and $M$. This hypothesis is supported by the fact that MDM2 can inhibit the activity of the $\mathrm{p} 53$ and the $\mathrm{Rb}$ tumor suppressors (Momand et al. 1992; Chen et al. 1993, 1995; Oliner et al. 1993; Xiao et al. 1995), and can stimulate the activity of the E2F1 transcriptional activator (Martin et al. 1995). E2F1 induces expression of a variety of genes necessary for DNA synthesis, such as DNA polymerase $\alpha$, thymidylate synthase, PCNA, ribonucleotide reductase, thymidine kinase, and dihydrofolate reductase (DeGregori et al. 1995). Thus, one possible

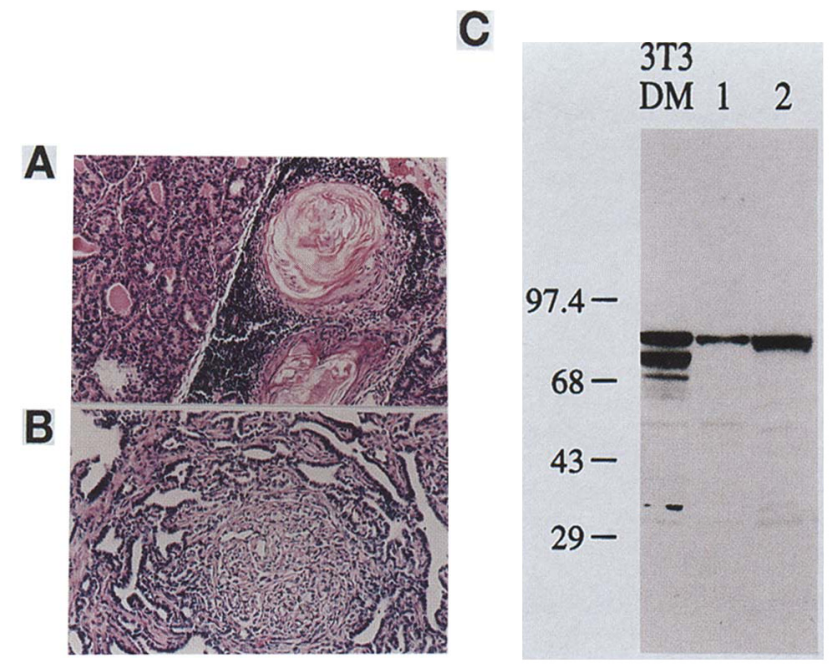

Figure 8. Histological and Western blot analysis of mammary tumors from BLGMDM2 transgenic mice. (A) A carcinoma (left) was found adjacent to an adenoacanthoma (right) in mammary gland $3 \mathrm{~L}$ from founder TG3643. $(B)$ An adenocarcinoma from a first-generation TG 3643 mouse. $(A, B)$ Magnification, 200×. $(C)$ Western blot analysis to detect MDM2 in tumors of transgenic mice. (Lane 1) 3T3 DM cell lysate; (lane 2) tumor lysate from TG3643 founder; (lane 3) tumor lysate from TG3646 founder. 
mechanism that can explain this transgenic phenotype is that overexpression of MDM2 constitutively augments E2F1, an activity that keeps the cells in $S$ phase. Numerous studies have demonstrated, however, that inappropriate expression of E2Fl results in the initiation of $S$ phase followed by p53-mediated apoptosis (Qin et al. 1994; Shan and Lee 1994; Wu and Levine 1994; Hiebert et al. 1995). The lack of apoptosis observed in our system was most likely attributable to the ability of MDM2 to also inhibit p53 function. We are currently testing this hypothesis.

Another important observation made in our study is that deregulated expression of $m d m 2$ leads to tumor development. Approximately $16 \%$ of transgenic mice overexpressing MDM2 developed mammary adenocarcinomas and adenocanthomas following a latency period of 14-18 months. These data provide direct evidence in vivo that $m d m 2$ deregulation causes tumor formation. In the BLGMDM2 mammary glands, MDM2 expression decreased in most of the epithelial cells after weaning and the cells were cleared through involution. However, the small percentage of mammary epithelial cells that persisted through each cycle (some of which may have been polyploid) were perhaps genetically unstable. Secondary mutations could accumulate that would allow these epithelial cells to retain deregulated expression of MDM2 and to overcome the uncoupling of $\mathrm{S}$ phase from mitosis and cycle normally. A critical role for MDM2 in this system could be inhibition of wild-type p53 function leading to tumor formation.

This collection of cellular and glandular abnormalities seen in the BLGMDM2 transgenic mice appears to be unique compared with other transgenic mice expressing oncogenes in the mammary gland (Cardiff and Munn 1995). Some aspects of the phenotypes we observed, for example, lactation difficulties and adenocarcinomas with varying latency, have been observed in transgenic mice overexpressing the neu, Wnt-1, or cyclin Dl oncogenes (Muller et al. 1988; Tsukamoto et al. 1988; Wang et al. 1994). However, poor glandular development as seen in the BLGMDM2 transgenics contrasts the glandular hyperplasia seen in these other mice. In addition, our studies have addressed changes in ploidy and multiple rounds of DNA synthesis in the abnormal mammary epithelial cells.

Previous results had suggested that $m d m 2$ amplification would have the same effect as mutational inactivation of p53, because MDM2 can bind to and inactivate p53. The results of this study demonstrate for the first time that MDM2 has a role independent of inhibition of p53 function. In one study of human sarcomas, the immunohistochemical detection of both mutant p53 and MDM2 proteins in the same tumors correlated with poor survival of the patients (Cordon-Cardo et al. 1994). Taken together, these findings imply that MDM2 may play a larger role in cellular transformation than simply inactivating $\mathrm{p} 53$. Although the shortened lifespan of the p53 null mouse (Donehower 1992; Jacks et al. 1994) prevents an analysis of tumor formation in the MDM2 transgenic in the absence of p53 function, experiments are under way to determine whether overproduction of MDM2 and p53 mutant protein increases the tumor rate in transgenic mice.

In conclusion, deregulated expression of MDM2 in the mammary gland of transgenic mice uncouples $S$ phase and mitosis, leading to cellular defects including polyploidy. This phenotype ultimately leads to mammary tumorigenesis. In humans, the vast majority of the documented cases of $m d m 2$ amplification/overexpression are found in human sarcomas, a tumor derived from mesenchymal lineage. Our data suggest that MDM2 may play a role in tumors of other cell lineages as well.

\section{Materials and methods}

Generation of transgenic mice

The ovine $\beta$-lactoglobulin promoter expression vector was a gift from A.J. Clark (Edinburgh Research Station, Scotland, UK). An $\mathrm{mdm} 2$ minigene bearing two introns was constructed by replacement of the AatII-EcoO109I cDNA fragment with the corresponding fragment ( $1400 \mathrm{bp}$ ) from the $m d m 2$ minigene containing introns 7 and 8 (Montes de Oca Luna et al. 1996). An $E c o R V$ fragment containing the $m d m 2$ minigene was subcloned into the $E c o \mathrm{RV}$ site of the $\beta$-lactoglobulin expression vector (Harris et al. 1991; Bortner and Rosenberg 1995). Digestion with Sall and $\mathrm{XbaI}$ released the $9.7-\mathrm{kb}$ transgene from the vector. The fragment was purified on a $0.8 \%$ low melting agarose gel by cutting out the transgenic fragment and digesting with GELase (Epicentre). The DNA was then purified by Resource $\mathrm{Q}$ anion exchange FPLC (Pharmacia) and ethanol precipitated. The fragment was resuspended in $10 \mathrm{~mm}$ Tris ( $\mathrm{pH} 7.4), 0.1 \mathrm{~mm}$ EDTA at a final concentration of $3 \mathrm{ng} / \mu \mathrm{l}$. The construct was coinjected with a dominant coat color marker (Kucera et al. 1996). Microinjection of $\mathrm{B} 6 \mathrm{C} 3 \mathrm{~F} 2$ zygotes was performed as described previously (Osborn et al. 1987). Mice with the p53 null allele were obtained from Tyler Jacks (Jacks et al. 1994) and backcrossed onto C57B1/6J.

\section{PCR analysis and Southern blotting}

DNA was isolated from 1-cm tail biopsies and subjected to PCR analysis. Two different primer sets were used to identify transgenic animals. One set spans the BLG promoter/MDM2 transgene junction. The forward primer is in the BLG promoter (BLG 5 -CCTGTCCTTGTCTAAGAGGCTGAC- $3^{\prime}$ ), and the reverse primer is in the mdm2 gene (MDM2 5'-CGAAGCTGGAATCTGTGAGGTG-3') and yields a PCR fragment of 590 bases. The second set of primers amplifies a fragment from the BLG promoter (F2 5'-CCGTCCTGGGGTTATTATGACTC-3'; B2 5'TCCAAACCATGTGACCGTGG-3') and yields a predicted fragment of 200 bases. In genotyping the p53-/- animals, primers X6.5 (5'-ACAGCGTGGTGGTACCTTAT-3') and X7 (5'TATACTCAGAGCCGGCCT-3') gave a 375 -bp band for the wild-type allele and MCI (5'-ATCAGGACATAGCGTTGGCTACCC-3') and X7 gave a 525-bp band for the p53-/- allele (Jacks et al. 1994). Both bands were visible in p53+/- animals. PCR assay conditions were $10 \mathrm{~mm}$ Tris- $\mathrm{HCl}(\mathrm{pH} 8.3), 50 \mathrm{~mm}$ $\mathrm{KCl}, 1.5 \mathrm{~mm} \mathrm{MgCl}, 10 \mu \mathrm{M}$ of deoxynucleotide triphosphate mixture, $0.65 \mathrm{ng} / \mathrm{\mu l}$ of primers, $3 \mu \mathrm{l}$ of 1:100 dilution of tail DNA, and 0.5 units of native Taq DNA polymerase (Perkin Elmer-Cetus) in a $50-\mu$ l reaction mixture. Forty cycles of denaturation $\left(1 \mathrm{~min}, 94^{\circ} \mathrm{C}\right)$, annealing $\left(1 \mathrm{~min}, 52^{\circ} \mathrm{C}\right)$, and extension $(2$ min, $72^{\circ} \mathrm{C}$ ) were performed in a Techne PHC-3 thermal cycler. Founder animals that were positive in the PCR assay were con- 
firmed by Southern blotting analysis. Approximately $10 \mu \mathrm{g}$ of genomic tail DNA was digested with BamHI and electrophoresed on a $0.8 \%$ agarose gel. The DNA was transferred to a nitrocellulose membrane using standard procedures (Sambrook et al. 1989| and hybridized with a radiolabeled 1.5 -kb BamHISphI fragment from the BLG promoter, yielding a band at $2.2 \mathrm{~kb}$ that is specific for the transgene.

\section{Preparation and analysis of RNA}

Total cellular RNA was prepared from mouse tissues using Tri Reagent (Molecular Research Center, Inc.) according to the manufacturer's instructions. RNA expression was analyzed in a T2 RNase protection assay. To make the MDM2 antisense probe the $B a m H I$ fragment of the $m d m 2$ minigene was subcloned into Bluescript $\mathrm{KS}^{+}$(Stratagene). The plasmid was linearized at the Sall site and used as a template for in vitro transcription with T7 RNA polymerase (Boehringer Mannheim). For an internal control, a 300-nucleotide antisense riboprobe for the $\beta$-actin gene (Ambion) was synthesized. Twenty-five to fifty micrograms of total cellular RNA was combined with $5 \times 10^{5}$ to $1 \times 10^{6} \mathrm{cpm}$ of synthesized probe and ethanol-precipitated and dried. The pellet was resuspended in $40 \mu \mathrm{l}$ of hybridization buffer containing $80 \%$ formamide, $40 \mathrm{~mm} \mathrm{1,4}$ piperazinediethanesulfonic acid (PIPES, pH 6.7), $0.4 \mathrm{M} \mathrm{NaCl}$, and $1 \mathrm{mM}$ EDTA and incubated overnight at $60^{\circ} \mathrm{C}$. Three hundred and fifty microliters of ice-cold T2 RNase digestion buffer [50 mM sodium acetate $(\mathrm{pH} 4.5), 2 \mathrm{~mm}$ EDTA, $100 \mathrm{~mm} \mathrm{NaCl}]$ containing 20 units $/ \mathrm{ml}$ of T2 RNase were added to each sample an incubated at $33^{\circ} \mathrm{C}$ for $1 \mathrm{hr}$. Samples were ethanol-precipitated, resuspended in $8 \mu \mathrm{l}$ of gel loading buffer (Ambion), subjected to electrophoresis through a $5 \%$ polyacrylamide gel, and analyzed by autoradiography.

\section{Histology and immunohistochemistry}

Tissues obtained from animal necropsies or mammary gland biopsies were fixed in Z-fix neutral buffered formalin (Anatech) or Bouin's fixative (Sigma). Five-micrometer thick paraffin sections were stained with H\&E for histological analysis. Mice received an intraperitoneal injection of BrdU (Boehringer-Mannheim) at $120 \mathrm{mg}$ per $\mathrm{kg}$ body weight $1-1.5 \mathrm{hr}$ before sacrifice to label cells in S phase (Kim et al. 1993). For BrdU, PCNA, and MDM2 staining, 5- $\mu \mathrm{m}$ thick sections were placed on ProbeOn ${ }^{+}$ slides (Fisher Scientific) to insure adhesion during processing. Tissue sections were incubated with a monoclonal antibody to BrdU (1:500, Accurate Chemical and Scientific Corporation) or PCNA (1:500, Dako Corporation). Rabbit polyclonal antiserum specific for the MDM2 protein was a generous gift from Arnold Levine (Princeton University). The MDM2 antiserum was diluted 1:250 for immunocytochemistry. The primary antibodies were detected using the Vectastain $\mathrm{ABC}$ immunoperoxidase system with $3,3^{\prime}$-diaminobenzidine tetrahydrochloride (DAB) as the chromagen substrate. In addition, the DAB enhancer (Zymed) was used for MDM2 detection. Positive staining for PCNA was determined based on cellular distribution and intensity of the brown to black staining, which correlates with the different phases of the cell cycle as reported previously (Eldridge et al. 1990, 1993; Foley et al. 1991). For whole-mount analysis, the first abdominal (4th) mammary gland was dissected and stretched on a glass slide. After air drying, the gland was defatted and fixed overnight in acetone. The glands were then stained in Harris' hematoxylin overnight, destained in a solution of $2 \%$ $\mathrm{HCl}$ in $70 \%$ ethanol, and dehydrated in a graded ethanol series. The dehydrated tissue was cleared overnight in toluene and mounted.

\section{Ploidy analysis}

Paraffin sections were cut $6 \mu \mathrm{m}$ thick and placed on Probe $\mathrm{On}^{+}$ slides. Tissue sections were stained using the Feulgen staining kit (Becton Dickinson Cellular Imaging systems). An unstained calibration slide and an unstained mammary sample were included as method controls in the staining procedure. Nuclei in sections from nontransgenic control mammary epithelial cells were used to establish the 2N DNA content using DNA Image Cytometry (Roche Pathology WorkStation, Roche Image Analysis Systems, Inc., now LabCorp). The optical density of nuclei from transgenic mice was quantitated relative to the control nuclei (Schulte and Wittekind 1989; Cohen 1996; Marchevsky et al. 1996). The OD of $\sim 100$ nuclei per sample was determined, and the results were graphed. The prominent histogram peaks were labeled to give an overall DNA index for each peak (LabCorp, Research Triangle Park, NC).

\section{Western blot analysis}

At necropsy, tissues were frozen at $-70^{\circ} \mathrm{C}$. For Western analysis, lysates of tissues were made in lysis buffer $150 \mathrm{~mm}$ Tris at $\mathrm{pH}$ 7.4, $5 \mathrm{~mm}$ EDTA, $150 \mathrm{~mm} \mathrm{NaCl}, 1 \%$ Triton X-100, 0.1\% SDS, $1 \%$ sodium deoxycholate) containing protease inhibitors by dounce homogenization followed by sonication. For an MDM2 control, 3T3 DM cell (Fakharzadeh et al. 1991) pellets were lysed in $50 \mathrm{~mm}$ Tris at $\mathrm{pH} 8,5 \mathrm{~mm}$ EDTA, $150 \mathrm{~mm} \mathrm{NaCl}$, and $0.5 \%$ NP40 containing protease inhibitors. After centrifugation, a protein assay (Biorad) was used to determine the protein concentration of lysates. Fifty micrograms of protein lysate were loaded on a $4 \%-12 \%$ NuPAGE gradient gel (Novex) and electrophoresed at $200 \mathrm{~V}$. Proteins were transferred to nitrocellulose using the NuPAGE (Novex) transfer system according to the manufacturer's instructions. Blots were blocked with $2.5 \%$ milk in TBS-T for $1 \mathrm{hr}$ and then incubated with an MDM2specific polyclonal antiserum at 1:500 dilution for $1 \mathrm{hr}$ at room temperature. After being washed in five changes of TBS- $T$, the blot was incubated with a Donkey anti-rabbit antibody (Amersham) at a 1:4000 dilution for $1 \mathrm{hr}$ at room temperature. The MDM2 protein was detected using the ECL detection system (Amersham).

\section{Acknowledgments}

We thank Rusty Murray and Diane Hawkins-Brown for excellent technical assistance and Cathy Powell for her exceptional work on the ploidy analysis. Ruth Lightfoot, Mary Horne, Sandy Eldridge, and Mike Jokinen are thanked for pathology support, Gary Kucera for advice on genotype analysis, Jennifer Johnson for the 3T3DM pellets, and Donna Ferrell for artistic assistance. We also wish to thank Donna Bortner, Mike Colman, and Valerie Reinke for helpful discussions and critical comments on the manuscript. This study was supported in part by a grant from the Department of Army Medical Division (DAMD17-961-6222 to G.L.) and core grant CA16672.

The publication costs of this article were defrayed in part by payment of page charges. This article must therefore be hereby marked "advertisement" in accordance with 18 USC section 1734 solely to indicate this fact.

\section{References}

Amundadottir, L.T., G. Merlino, and R.B. Dickson. 1996. Transgenic mouse models of breast cancer. Breast Cancer Res. Treat. 39: 119-135.

Barak, Y., T. Juven, R. Haffner, and M. Oren. 1993. mdm2 expression is induced by wild type p53 activity. EMBO I. 
12: $461-468$,

Bortner, D.M. and M.P. Rosenberg. 1995. Overexpression of cyclin $\mathrm{A}$ in the mammary glands of transgenic mice results in the induction of nuclear abnormalities and increased apoptosis. Cell Growth \& Differ. 6: 1579-1589.

Cahilly-Snyder, L., T. Yang-Feng, U. Francke, and D.L. George. 1987. Molecular analysis and chromosomal mapping of amplified genes isolated from a transformed mouse 3T3 cell line. Somat. Cell Mol. Genet. 13: 235-244.

Cardiff, R.D. and W.J. Muller. 1993. Transgenic mouse models of mammary tumorigenesis. Cancer Surveys 16: 97-113.

Cardiff, R.D. and R.J. Munn. 1995. Comparative pathology of mammary tumorigenesis in transgenic mice. Cancer Lett. 90: $13-19$.

Chen, J., V. Marechal, and A.J. Levine. 1993. Mapping of the p53 and $\mathrm{mdm}-2$ interaction domains. Mol. Cell. Biol. 13: 41074114.

Chen, J., J. Lin, and A.J. Levine. 1995. Regulation of transcription functions of the $\mathrm{p} 53$ tumor suppressor by the $\mathrm{mdm}-2$ oncogene. Mol. Med. 1: 142-152.

Chen, J., X. Wu, J. Lin, and A.J. Levine. 1996. mdm-2 inhibits the $G_{1}$ arrest and apoptosis functions of the p53 tumor suppressor protein. Mol. Cell. Biol. 16: 2445-2452.

Cohen, C. 1996. Image cytometric analysis in pathology. Hum. Pathol. 27: 482-493.

Cordon-Cardo, C., E. Latres, M. Drobniak, M.R. Oliva, D. Pollack, J.M. Woodruff, V. Marechal, J. Chen, M.F. Brennan, and A.J. Levine. 1994. Molecular abnormalities of $\mathrm{mdm} 2$ and $\mathrm{p} 53$ genes in adult soft tissue sarcomas. Cancer Res. 54: 794-799.

DeGregori, J., T. Kowalik, and J.R. Nevins. 1995. Cellular targets for activation by the E2F1 transcription factor include DNA synthesis- and G1/S-regulatory genes. Mol. Cell. Biol. 15: 4215-4224.

Donehower, L.A., M. Harvey, B.L. Slagle, M.J. McArthur, C.A. Montgomery, Jr., J.S. Butel, and A. Bradley. 1992. Mice deficient for p53 are developmentally normal but susceptible to spontaneous tumors. Nature 356: 215-221.

Eldridge, S.R., L.F. Tilbury, T.L. Goldsworthy, and B.E. Butterworth. 1990. Measurement of chemically-induced cell proliferation in rodent liver and kidney: A comparison of 5-bromo-2'-deoxyuridine and $\left[{ }^{3} \mathrm{H}\right]$ thymidine administered by injection or osmotic pump. Carcinogenesis 11: 22452251.

Eldridge, S.R., B.E. Butterworth, and T.L. Goldsworthy. 1993. Proliferating cell nuclear antigen: A marker for hepatocellular proliferation in rodents. Environ. Health Perspect. (Suppl 5) 101: 211-218.

Fakharzadeh, S.S., S.P. Trusko, and D.L. George. 1991. Tumorigenic potential associated with enhanced expression of a gene that is amplified in a mouse tumor cell line. EMBO $I$. 10: $1565-1569$.

Finlay, C.A. 1993. The mdm-2 oncogene can overcome wildtype p53 suppression of transformed cell growth. Mol. Cell. Biol. 13: 301-306.

Foley, J.F., D.R. Dietrich, J.A. Swenberg, and R.R. Maronpot. 1991. Detection and evaluation of proliferating cell nuclear antigen (PCNA) in rat tissue by an improved immunohistochemical procedure. $I$. Histotechnol. 14: 237-241.

Fontana, X., P. Ferrari, M. Abbes, J. Monticelli, M. Namer, and F. Bussiere. 1994. Study of mdm2 gene amplification in primary breast tumors. Bull. Cancer 81: 587-592.

Harris, S., M. McClenaghan, I.P. Simons, S. Ali, and A.J. Clark. 1991. Developmental regulation of the sheep $\beta$-lactoglobulin gene in the mammary gland of transgenic mice. Dev. Genet. 12: 299-307.

Haupt, Y., Y. Barak, and M. Oren. 1996. Cell type-specific in- hibition of p53-mediated apoptosis by mdm2. EMBO I 15: 1596-1606.

Hiebert, S.W., G. Packham, D.K. Strom, R. Haffner, M. Oren, G. Zambetti, and J.L. Cleveland. 1995. E2F-1:DP-1 induces p53 and overrides survival factors to trigger apoptosis. Mol. Cell. Biol. 15: 6864-6874.

Jacks, T., L. Remington, B.O. Williams, E.M. Schmitt, S. Halachmi, R.T. Bronson, and R.A. Weinberg. 1994. Tumor spectrum analysis in p53-mutant mice. Curr. Biol. 4: 1-7.

Jones, S.N., A.E. Roe, L.A. Donehower, and A. Bradley. 1995. Rescue of embryonic lethality in $\mathrm{mdm} 2$-deficient mice by absence of p53. Nature 378: 206-208.

Juven, T., Y. Barak, A. Zauberman, D.L. George, and M. Oren. 1993. Wild type p53 can mediate sequence-specific transactivation of an internal promoter within the $m d m 2$ gene. Oncogene 8: 3411-3416.

Kim, S.H., K.A. Roth, A.R. Moser, and J.I. Gordon. 1993. Transgenic mouse models that explore the multistep hypothesis of intestinal neoplasia. I. Cell Biol. 123: 877-893.

Kucera, G.T., D.M. Bortner, and M.P. Rosenberg. 1996. Overexpression of an agouti cDNA in the skin of transgenic mice recapitulates dominant coat color phenotypes of spontaneous mutants. Dev. Biol. 173: 162-173.

Ladanyi, M., C. Cha, R. Lewis, S.C. Jhanwar, A.G. Huvos, and J.H. Healey. 1993. MDM2 gene amplification in metastatic osteosarcoma. Cancer Res. 53: 16-18.

Leach, F.S., T. Tokino, P. Meltzer, M. Burrell, J.D. Oliner, S. Smith, D.E. Hill, D. Sidransky, K.W. Kinzler, and B. Vogelstein. 1993. p53 mutation and MDM2 amplification in human soft tissue sarcomas. Cancer Res. 53: 2231-2234.

Li, M., J. Hu, K. Heermeier, L. Hennighausen, and P.A. Furth. 1996. Expression of a viral oncoprotein during mammary gland development alters cell fate and function: Induction of p53-independent apoptosis is followed by impaired milk protein production in surviving cells. Cell Growth \& Differ. 7:3-11.

Marchetti, A., F. Buttitta, S. Girlando, P. Dalla Palma, S. Pellegrini, P. Fina, C. Doglioni, G. Bevilacqua, and M. Barbareschi. $1995 . \mathrm{mdm} 2$ gene alterations and $\mathrm{mdm} 2$ protein expression in breast carcinomas. I. Pathol. 175: 31-38.

Marchevsky, A., T. Tolmachoff, and S. Lee. 1996. Quality assurance issues in DNA image cytometry. Cytometry 26: 101-107.

Martin, K., D. Trouche, C. Hagemeier, T.S. Sorensen, N.B. La Thangue, and T. Kouzarides. 1995. Stimulation of E2F1/DP1 transcriptional activity by MDM2 oncoprotein. Nature 375: 691-694.

McCann, A.H., A. Kirley, D.N. Carney, N. Corbally, H.M. Magee, G. Keating, and P.A. Dervan. 1995. Amplification of the MDM2 gene in human breast cancer and its association with MDM2 and p53 protein status. Br. I. Cancer 71: 981-985.

Momand, J., G.P. Zambetti, D.C. Olson, D. George, and A.J. Levine. 1992. The mdm-2 oncogene product forms a complex with the p53 protein and inhibits p53-mediated transactivation. Cell 69: 1237-1245.

Montes de Oca Luna, R., D.S. Wagner, and G. Lozano. 1995. Rescue of early embryonic lethality in mdm2-deficient mice by deletion of p53. Nature 378: 203-206.

Montes de Oca Luna, R., A.D. Tabor, H. Eberspaecher, D.L. Hulboy, L.L. Worth, M.S. Colman, C.A. Finlay, and G. Lozano. 1996. The organization and expression of the $\mathrm{mdm} 2$ gene. Genomics 33: 352-357.

Muller, W.J., E. Sinn, P.K. Pattengale, R. Wallace and P. Leder. 1988. Single-step induction of mammary adenocarcinoma in transgenic mice bearing the activated c-neu oncogene. Cell 54: 105-115. 
Oliner, J.D., K.W. Kinzler, P.S. Meltzer, D.L. George, and B. Vogelstein. 1992. Amplification of a gene encoding a p53associated protein in human sarcomas. Nature 358: 80-83.

Oliner, J.D., J.A. Pietenpol, S. Thiagalingam, J. Gyuris, K.W. Kinzler, and B. Vogelstein. 1993. Oncoprotein MDM2 conceals the activation domain of tumour suppressor p53. $\mathrm{Na}$ ture 362: 857-860.

Osborn, L., M.P. Rosenberg, S.A. Keller, and M.H. Meisler. 1987. Tissue-specific and insulin-dependent expression of a pancreatic amylase gene in transgenic mice. Mol. Cell. Biol. 7: 326-334.

Qin, X.-Q., D.M. Livingston, W.G. Kaelin, Jr., and P.D. Adams. 1994. Deregulated transcription factor E2F-1 expression leads to S-phase entry and p53-mediated apoptosis. Proc. Natl. Acad. Sci. 91: 10918-10922.

Quesnel, B., C. Preudhomme, J. Fournier, P. Fenaux, and J.P. Peyrat. 1994. MDM2 gene amplification in human breast cancer. Eur. I. Cancer 30a: 982-984.

Reifenberger, G., L. Liu, K. Ichimura, E.E. Schmidt, and V.P. Collins. 1993. Amplification and overexpression of the MDM2 gene in a subset of human malignant gliomas without p53 mutations. Cancer Res, 53: 2736-2739.

Sambrook, J., E.F. Fritsch, and T. Maniatis. 1989. Molecular cloning: A laboratory manual, 2nd ed. Cold Spring Harbor Laboratory, Cold Spring Harbor, NY.

Schulte, E. and D. Wittekind. 1989. Standardization of the Feulgen-Schiff technique. Histochemistry 91: 321-331.

Shan, B. and W.H. Lee. 1994. Deregulated expression of E2F-1 induces S-phase entry and leads to apoptosis. Mol. Cell. Biol. 14: 8166-8173.

Sheikh, M.S., Z.M. Shao, A. Hussain, and J.A. Fontana. 1993. The p53-binding protein MDM2 gene is differentially expressed in human breast carcinoma. Cancer Res. 53: 32263228.

Tsukamoto, A.S., R. Grosschedl, R.C. Gusman, T. Parslow, and H.E. Varmus. 1988. Expression of the int-1 gene in transgenic mice is associated with mammary gland hyperplasia and adenocarcinomas in male and female mice. Cell 55: 619_ 625.

Wang, T.C., R.D. Cardiff, L. Zukerberg, E. Lees, A. Arnold, and E.V. Schmidt. 1994. Mammary hyperplasia and carcinoma in MMTV-cyclin D1 transgenic mice. Nature 369: 669-671.

$\mathrm{Wu}, \mathrm{X}$. and A.J. Levine. 1994. P53 and E2F-1 cooperate to mediate apoptosis. Proc. Natl. Acad. Sci. 91: 3602-3606.

Wu, X., J.H. Bayle, D. Olson, and A.J. Levine. 1993. The p53mdm-2 autoregulatory feedback loop. Genes \& Dev. 7: 1126-1132.

Xiao, Z.X., J. Chen, A.J. Levine, N. Modjtahedi, J. Xing, W.R. Sellers, and D.M. Livingston. 1995. Interaction between the retinoblastoma protein and the oncoprotein MDM2. Nature 375: $694-698$ 


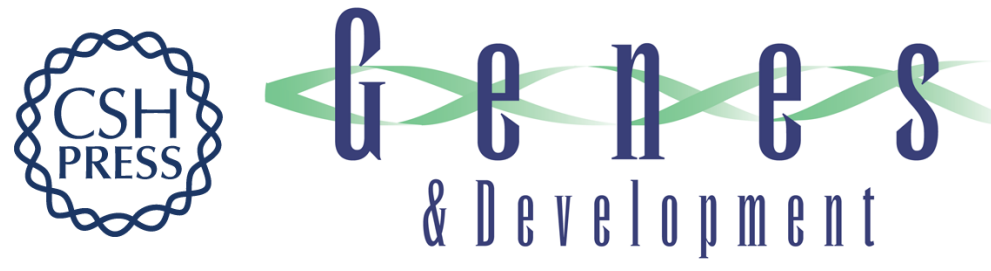

\section{Targeted expression of MDM2 uncouples S phase from mitosis and inhibits mammary gland development independent of p53.}

K Lundgren, R Montes de Oca Luna, Y B McNeill, et al.

Genes Dev. 1997, 11:

Access the most recent version at doi:10.1101/gad.11.6.714

References This article cites 52 articles, 17 of which can be accessed free at: http://genesdev.cshlp.org/content/11/6/714.full.html\#ref-list-1

License

Email Alerting

Service

Receive free email alerts when new articles cite this article - sign up in the box at the top right corner of the article or click here.

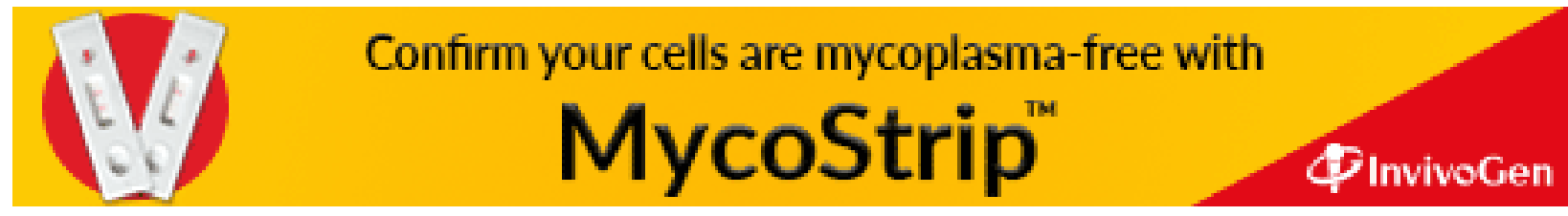

